Ольга Лазоркина

\title{
Беларусь - Венгрия: паттерн взаимодействия в условиях ассиметричных объединений
}

\section{Вступление}

Межгосударственные отношения как объект исследования представляют особый интерес. Сегодня под воздействием процессов регионализации и глобализации созданы и функционируют региональные объединения, которые в значительной степени отвлекают внимание исследователей от собственно двусторонней проблематики отношении государств. Неизменный интерес к данному формату проявляется, как правило, в отношении крупных игроков на международной арене, так как от его динамики зависят множество других участников. В этой связи отношения государств, относящихся к категории средних и малых, как правило изучаются сквозь призму региональной надстройки. Логичным в этом контексте являются вопросы, что представляет собой двусторонний формат отношений государств такого уровня, какие модели сотрудничества могут рассматриваться в качестве оптимальных?

Республика Беларусь и Венгрия относятся к категории средних по уровню государств, являются членами крупных интеграционных объединений, ассиметричных по своему характеру. Это означает, что они приняли условия и вынуждены на постоянной основе координировать свои действия с остальными участниками. Следовательно, изучение динамики отношений между ними позволит дать ответ на поставленные выше вопросы.

\section{Взвешенный политический диалог}

Конец 80-х - начало 90-х гг. ХХ в. для двух государств имел историческое значение. В 1989 г. в Венгрии прошла „бархатная” революция, которая положила начало новому этапу государственного строительства, уже 
на демократических основах ${ }^{1}$ В 1991 г. белорусы получили долгожданную и выстраданную возможность образовать независимое государство - Республику Беларусь. Дипломатическое признание Республики Беларусь встретило широкую поддержку со стороны зарубежных государств. С Венгерской Республикой дипломатические отношения были установлены 12 II 1992 г. ${ }^{2}$. Однако стороны не спешили с открытием посольств. Это было связано, в первую очередь, с ограниченными финансовыми возможностями. В 90-е гг. Республика Беларусь могла позволить себе открывать посольства только в тех странах, с которыми устанавливались тесные политические и экономические отношения. В 1994 г. Венгерская Республика подала заявку на вступление в Европейский союз. Республика Беларусь в свою очередь начала процесс интеграции с Российской Федерацией. Эти факторы в значительной степени влияли на интенсивность политического диалога. В 1996 г. после проведения референдума в Беларуси, отношения с ЕС в политической сфере претерпели заметные изменения, которые нашли свое выражение в осуждении белорусского руководства и непризнания его результатов. Вполне естественно, что страны, которые видели свое будущее с ЕС, присоединились к коллективному мнению. Кроме того, в этот период Венгерская Республика объявила о намерении вступить в НАТО. Таким образом, внешнеполитические ориентиры двух стран коренным образом отличались и не способствовали развитию отношений. В целом 90-е гг. были периодом становления внешнеполитического курса Беларуси и Венгрии, определения приоритетов на региональном и международном уровнях.

О качественно новом этапе в отношениях Беларуси и Венгрии можно говорить только с началом 2000-х гг. Трагические события 11 IX 2001 г. в США в значительной степени способствовали активизации сотрудничества всех стран перед лицом общей угрозы. Принадлежность к разным политическим и военным блокам уже не играла такой главенствующей роли. Кроме того, во внешней политике все большое значение приобретал экономический прагматизм, который оказывал заметное влияние на расширение сотрудничества государств.

Данные факторы способствовали активизации и белорусско-венгерского диалога. В 2000 г. в Будапеште было открыто посольство Республики Беларусь. Этот шаг в значительной степени способствовал повышению узнаваемости Беларуси в Венгрии ${ }^{3}$. Так в 2004 г. во время празднования

1 М.Э. Чесновский, Страны Средней Европы в международных отношениях (19892014 22.), Минск 2016, с. 101.

2 Двусторонние отночения с Венгрией, https://hungary.mfa.gov.by/ru/bilateral_relations/ political/ (24 VI 2020).

3 О вручении Президенту Беларуси верительных грамот послами Бангладеш, Венгрии и Ирландии (22 I 2000), https://mfa.gov.by/press/news_mfa/e65fe0619e6255bf.html (29 VI 2020). 
60-летия освобождения Беларуси от имени главы белорусского государства были вручены юбилейные медали ветеранам Второй мировой войны ${ }^{4}$.

Вместе с тем, в деле активизации политического диалога посольство может выполнять только вспомогательные функции. Беларусь не входила в список приоритетных политических и экономических партнеров Венгрии. Кроме того, страна была занята подготовкой к вступлению в Европейский союз, которое состоялось в 2004 г. Новые члены ЕС, в том числе и Венгрия, занялись поиском своего места в новом интеграционном объединении. Такая ниша была найдена в „европейской политике соседства”, которая переросла в зону особой ответственности за развитие сотрудничества со странами Восточной Европы и постсоветского пространства в целом. В этой связи выглядит вполне логичным открытие Венгрией посольства в Республике Беларусь в 2008 г. и в целом активизация сотрудничества по разным направлениям ${ }^{5}$. Очевидно, что Венгрия была заинтересована в изучении положения в Беларуси, которое помогло бы ей сформулировать предложения по формированию стратегии отношений со странами постсоветского пространства и выделению перспективных направлений сотрудничества. С 2008 г. стороны активизировали обмен визитами. И первым лицом, прибывшим в Беларусь стал Государственный секретарь Министерства иностранных дел Венгерской Республики Дьордь Гийян ${ }^{6}$. В ходе встречи состоялось обсуждение актуальных вопросов двустороннего сотрудничества - развитие политического диалога и экономических связей. Кроме того, важными темами в повестке встречи стали перспективы взаимодействия в рамках многостороннего формата - Вышеградской группы и ЕС в целом.

С ответным визитом в октябре того же года в Будапешт прибыл заместитель министра иностранных дел Республики Беларусь В. Воронецкий. Как отметили в пресс-релизе МИД Беларуси в ходе встречи состоялось обсуждение актуальных вопросов политического сотрудничества. Стороны подтвердили необходимость укрепления формата межмидовских консультаций, которые в значительной степени способствовали осуществлению мониторинга и внесению необходимых изменений в двустороннюю повестку. Белорусская сторона выразила готовность развивать межпарламентское сотрудничество, пусковым механизмом которого стала группа венгерской-белорусской дружбы в парламенте Венгрии. В целом, визит можно

4 О мероприятиях, проводимых загранучреждениями Беларуси в рамках празднования 60-летия освобождения Беларуси (13 IX 2004), https://mfa.gov.by/press/news_mfa/ f78dcfa71b1bde00.html (1 VII 2020).

5 В Минске открылось посольство Венгрии (3 VI 2008), http://www.ctv.by/новости/новостиминска-и-минской-области/в-минске-открылось-посольство-венгрии (11 VII 2020).

6 О визите Государственного секретаря МИД Венгрии (2 VI 2008), http://mfa.gov.by/press/ news_mfa/f2edc7fd7aa1b028.html (3 VI 2020). 
назвать насыщенным и продуктивным. Так как были выражены не только намерения, но и подписаны важные соглашения. Венгрия ратифицировала соглашение об экономическом сотрудничестве и передало его белорусской стороне. Кроме того, было принято решение о создании межправительственной комиссии по экономическому сотрудничеству ${ }^{7}$. Следующий 2009 г. стал знаковым для развития сотрудничества ЕС со странами постсоветского пространства. А именно, была запущена инициатива „Восточное партнерство”. Однако Венгрия не являлась инициаторам данной инициативы и стала играть достаточно активную роль только тогда, когда бразды правления неформально перешли в компетенцию Вышеградской группы. Инициатива „Восточное партнерство” оказала заметное влияние на развитие диалога Беларуси с ЕС в целом и Венгрией, в частности ${ }^{8}$. Самым заметным событием, которое можно рассматривать как начало нового этапа в двусторонних отношениях, стал визит министра иностранных дел Республики Беларусь С. Мартынова в Будапешт. Программа визита была настолько насыщенной, что складывалось впечатление об определенном прорыве в отношениях. Белорусский министр провел встречи со своим венгерским коллегой. Кроме того, белорусская делегация отметила как содержательные, а значит имеющие практическую значимость переговоры в Правительстве и Государственном собрании Венгерской Республики. Но самым знаковым стало назначение даты визита на дни проведения многосторонней встречи министров иностранных дел в формате „Вышеградской группы”, „Восточного партнерства”, стран Балтии и „тройки” председателей ЕС. Министр иностранных дел Республики Беларусь не просто принял участие во встрече, а озвучил белорусскую инициативу суть которой сводилась к созданию особого формата взаимодействия в рамках „Восточного партнерства”, который подразумевал создание сети банковского, промышленного и бизнес-секторов с целью разработки и реализации взаимовыгодных для стран проектов. Блестящий визит белорусского министра завершился лекцией Венгерском институте по вопросам международной политики ${ }^{9}$ К сожалению, период роста был более чем кратким и сменился спадом, в первую очередь в политической сфере. Это было связано с вы-

7 Беларусь и Венгрия обсудили вопросы политического взаимодействия (30 X 2008), https://naviny.by/rubrics/politic/2008/10/30/ic_news_112_300791 (10 VI 2020); Д.А. Тарас, Белорусско-венгерские отночения: 25 лет политического и экономического прагматизма, [в:] Новые возможности переформатирования системы международных отномений, Минск 2017, с. 84-91.

8 Ф. Контра, Дружить могут не только соседи, „Беларуская думка” 2009, №8, с. 44-51.

9 Об официальном визите Министра иностранных дел Беларуси в Венгрию (3 III 2010), https://www.belarus.by/ru/press-center/press-release/ob-ofitsialnom-vizite-ministra-inostrannyx-del-belarusi-v-vengriju_i_0000000822.html_(15 VI 2020). 
борами главы белорусского государства, которые прошли в декабре 2010 г. ЕС выступил с жесткой критикой белорусских властей и Венгрия полностью поддержала позицию Брюсселя ${ }^{10} .2011$ г. был годом председательства Венгрии в ЕС и белорусская сторона всерьез рассчитывала на поддержку. Однако в течение всего года санкции и визовые ограничения только расширялись. Тем не менее, на фоне сложных отношений состоялся визит в Будапешт зам. министра иностранных дел Республики Беларусь В. Воронецкого $^{11}$. В ходе визита стороны обсудили актуальные вопросы двусторонних отношений и выразили намерения дальнейшего развития сотрудничества. В сложившихся условиях визит можно было рассматривать как попытку выразить своего рода поддержку Беларуси. При этом политический диалог в фазу развития так и не перешел, остановив свое поступательное движение до 2015 г. Позитивные тенденции в двусторонних отношениях стали просматриваться на фоне изменения отношения ЕС к Беларуси в целом. Спустя пять лет в Минск с ответным визитом прибыл министр иностранных дел и внешней торговли Венгрии П. Сийярто. Встреча прошла на достаточно высоком уровне. Белорусская сторона подчеркнула важность визита переговорами с Премьер-министром и министром иностранных дел. Белорусский министр В. Макей отметил такую особенность двусторонних отношений как стремление сторон фокусироваться на объединяющих моментах $^{12}$. В стенограмме подхода к прессе была упомянута программа правительства Венгрии „Открытие на Восток”. Однако Беларусь можно было рассматривать только как промежуточное звено, Венгрию интересовали, прежде всего, перспективные рынки Российской Федерации и азиатских государств ${ }^{13}$.

В феврале 2016 г. ЕС официально отменил санкции в отношении Республики Беларусь ${ }^{14}$. А в марте 2016 г. состоялся визит главы белорусского

10 European Parliament resolution of 20 January 2011 on the situation in Belarus (20 I 2011), https://www.europarl.europa.eu/doceo/document/TA-7-2011-0022_EN.html?redirect (3 VI 2020).

11 Вопросы сотрудничества Беларуси и ЕС обсуждены во время визита белорусской делегащии в Венгрию и Словению (13 IV 2011), https://www.belta.by/politics/view/voprosysotrudnichestva-belarusi-i-es-obsuzhdeny-vo-vremja-vizita-belorusskoj-delegatsii-vvengriju-i-s-128488-2011 (22 VI 2020).

12 Стенограмма подхода к прессе Министра иностранных дел Республики Беларусь Владимира Макея и Министра иностранных дел и внешней торговли Венгрии Петера Сийярmo (29 IV 2015), http://mfa.gov.by/press/news_mfa/efe3f9608b0cc4c6.html (25 VI 2020).

13 B. Zsolt, A keleti nyitás súlya a magyar külgazdaságban (14 III 2014), https://polgariszemle. hu/archivum/87-2014-marcius-10-evfolyam-1-2-szam/tudomanyos-muhelyek/594-a-keletinyitas-sulya-a-magyar-kuelgazdasagban (19 VI 2020).

14 Council conclusions on Belarus (15 II 2016), https://www.consilium.europa.eu/en/press/pressreleases/2016/02/15/fac-belarus-conclusions/ (17 VI 2010). 
МИД В. Макея в Венгрию. Главным итогом стало не просто обсуждение перспектив взаимодействия, а подписание своего рода „дорожной карты” сотрудничества двух ведомств. Глава МИД провел встречи с зам. Премьер-министра и вице-спикером Парламента. Кроме того, В. Макей встретился с представителями венгерского бизнеса для обсуждения направлений взаимодействия ${ }^{15}$.

В дальнейшем поступательное развитие сотрудничества было продолжено. 25-летие установления дипломатических отношений было отмечено визитом зам. министра иностранных дел Республики Беларусь О. Кравченко в Будапешт ${ }^{16}$. Сторонам удалось удержать набранный темп и в последующие годы. Ключевым и логичным в процессе сближения стал визит премьер-министра Венгрии В. Орбана в июне 2020 г. Глава венгерского правительства отметил, что у стран не существует никаких политических столкновений, он искренне надеется, что „его визит станет значимым шагом в развитии двусторонних отношений"17. Вместе с тем, В. Орбан заметил, что Беларусь и Венгрия мало разговаривают, что удивительно при наличии постоянных контактов и обменов визитами высших должностных лиц.

В политической сфере необходимо отметить еще одно важное направление сотрудничества - парламентское. Данное измерение зачастую недооценивают. Вместе с тем оно имеет достаточно серьезный потенциал для углубления понимания сторон и улучшения имиджа страны. Парламентарии имеют особый статус - представителей не только власти, но и народа. Республика Беларусь уделяет заметное внимание данному направлению в развитии сотрудничества с европейскими государствами. В отношениях с Венгрией наблюдаются одни из наиболее значимых достижений. С 2009 г. парламенты двух стран ведут достаточно активное взаимодействие. До настоящего времени в Государственном собрании Венгрии создана и действует группа дружбы с Беларусью под председательством вице-спикера. В 2016 г. Минск посетил Председатель Комиссии по международным делам Государственного собрания Венгрии Ж. Немет ${ }^{18}$. Соответствующая

15 Об официальном визите Министра иностранных дел Республики Беларусь В. Макея в Венгрию (17 III 2016), http://mfa.gov.by/press/news_mfa/db06378d3cf5ed1a.html (27 VI 2020).

16 О визите заместителя Министра иностранных дел Беларуси О.Кравченко в Венгрию (10 II 2017), http://mfa.gov.by/press/news_mfa/f295c5c5e04e521f.html (28 VI 2020).

17 Премьер-министр Венгрии о визите в Беларусь: я приехал с искренними намерениями наладить сотрудничество (5 VI 2020), https://www.belta.by/president/view/premjer-ministr-vengrii-o-vizite-v-belarus-ja-priehal-s-iskrennimi-namerenijami-naladit-sotrudnichestvo393625-2020/?utm_source=belta\&utm_medium=news\&utm_campaign=accen (30 VI 2020).

18 Бусько предложил Венгрии восстановить полноценные парламентские контакты (28 IV 2016), https://www.belta.by/politics/view/busko-predlozhil-vengrii-vosstanovit-polnotsennye-parlamentskie-kontakty-191562-2016 (15 VI 2020). 
структура также функционирует и в Национальном собрании Республики Беларусь. В ходе практически всех встреч должностных лиц разного уровня отмечается наличие данного направления сотрудничества и его важность для дальнейшего углубления отношений.

\section{Региональное измерение двусторонних отношений Республики Беларусь и Венгрии}

В современных условиях многосторонний формат сотрудничества играет превалирующую роль в отношениях государств. Зачастую он стирает грани двустороннего формата и выносит значимые вопросы политической и экономической повестки на многосторонний уровень. Он тем более значим, когда государства являются членами разного рода объединений. Кроме того, экономическая взаимозависимость стран настолько сильна сегодня, что они постоянно нуждаются в координации своих действий по тем или иным причинам. Республика Беларусь и Венгрия придают важное значение участию в региональных организациях и инициативах, что позволяет им более эффективно реализовывать внешнеполитические и внешнеэкономические задачи. Наиболее значимыми, с точки зрения динамики двусторонних отношений, являются контакты в рамках Центрально-Европейской инициативы (ЦЕИ), Вышеградской группы и „Восточного партнерства”. Республика Беларусь входит в состав ЦЕИ с 1996 г. ${ }^{19}$ Инициатива „Восточное партнерство” стартовала в 2009 г. и Беларусь вошла в число стран, которым было предложено европейское видение развития интеграционных связей с ЕС. Вишеградская группа уделяет заметное внимание в своих проектах государствам постсоветского пространства, в том числе и Беларуси. В целом, можно сказать, что цели и задачи данных объединений и инициатив во многом совпадают, вместе с тем обладая разными механизмами, они позволяют расширить потенциал сотрудничества.

Среди преимуществ, которые они предоставляют для Беларуси, в частности, можно выделить следующие: это дополнительные площадки для представления интересов страны в ЕС; страны-участницы обладают определенной долей самостоятельности в решении разного рода вопросов без довлеющего влияния политической составляющей; возможность оперативно и предметно предложить и согласовать инициативы. Вместе с тем, необходимо отметить, что Беларусь не входит в приоритеты Венгрии в данных объединениях и инициативах. Так как ее усилия были сосредоточены на

19 Центрально-Европейская Инициатива, https://www.mfa.gov.by/mulateral/organization/ list/fc4c6e8b83b633be.html (7 VII 2020). 
Украине. В первую очередь это было связано с наличием венгерской диаспоры и трепетным отношением страны к защите ее интересов на территории любых государств, в том числе и в Украине. Несомненно стороны имеют дополнительную возможность для расширения контактов. Однако назвать региональное измерение действительно значимым для двусторонних отношений сложно. Логичным здесь является вопрос о критериях эффективности многостороннего формата. В целом, указанные выше задачи он выполняет. Но при этом внести заметные коррективы в политические отношения Беларуси с ЕС не в состоянии. Финансирование разного рода проектов в рамках инициатив осуществляется централизованно. Беларусь, несмотря на декларируемую заинтересованность в развитии сотрудничества в рамках „Восточного партнерству”, зачастую не имеет возможности для освоения выделяемых средств, так как законодательство страны не позволяет использовать средства по целевому назначению. В этой связи, никакая поддержка со стороны Венгрии не сможет сыграть роли при отсутствии внутренних возможностей. Если проанализировать приоритеты Беларуси, то в них ключевую роль играет продвижение экономических интересов. Белорусская экономика сосредоточена на экспорте. Однако Венгрия, прежде всего, член ЕС и вынуждена в вопросах торговли подчиняться внутренним правилам объединения. Таким образом, двусторонние возможности в этом направлении весьма ограничены.

\section{Экономическое измерение как ключевой фактор динамики сотрудничества}

Торгово-экономическое сотрудничество Беларуси и Венгрии регулируется Соглашением между Правительством Республики Беларусь и Правительством Венгерской Республики об экономическом сотрудничестве от 2008 г. ${ }^{20}$. Ранее в 2003 г. сторонами было подписано межведомственное соглашение между министерствами экономики Республики Беларусь и министерством экономики и транспорта Венгерской Республики ${ }^{21}$. В 2004 г. министерства иностранных дел двух стран приняли решение о создании

20 Соглашение между Правительством Республики Беларусь и Правительством Венгерской Республики об экономическом сотрудничестве (18 XII 2008), https://pravo.by/docu ment/?guid=2012\&oldDoc=2008-302/2008-302(005-011).pdf\&oldDocPage=5 (12 VII 2020).

21 Соглашение между Министерством экономики Республики Беларусь и Министерством экономики и транспорта Венгерской Республики о сотрудничестве (5 III 2003), https:// pravo.by/document/?guid=2012\&oldDoc $=2003-26 / 2003-26(004-021) \cdot$ pdf\&oldDocPage $=17$ (13 VII 2020). 
Рабочей группы по экономическому сотрудничеству и развитию торговли ${ }^{22}$. Характеризуя кратко данные соглашения, необходимо отметить, что договор от 2003 г. носил декларативный характер, выражал скорее намерения и определял самые общие направления сотрудничества. В отличие от него Рабочая группа, которая создавалась в рамках МИД двух стран, имела серьезную практическую направленность, что и было детально зафиксировано в документе. Особого внимания заслуживает выделение функций группы, которые были направлены на содействие расширению контактов деловых кругов, в том числе средних и мелких предпринимателей, обмены актуальной информацией о программах модернизации разных отраслей экономики с целью оперативного реструктуризации экспорта и импорта. Межправительственное соглашение таким образом знаменовало собой завершение процесса создания документальной базы экономического сотрудничества. Кроме того, данный документ зафиксировал реальную заинтересованность сторон в развитии экономического измерения двусторонних отношений. В Соглашении стороны выделили 20 областей перспективного долгосрочного сотрудничества.

Таким образом, можно предположить, что политика и экономика эффективно дополняли друг друга и развивались параллельно. Тем не менее, любые соглашения, как бы их не оценивать в теории, должны подтверждаться цифрами на практике. Итак, в 2003 г. объем взаимной торговли составил 143,3 млн USD с положительным сальдо. В 2004 г. показатели были улучшены до 192,5 млн USD. 2006 г. зафиксировал последовательный рост товарооборота до 209,6 млн USD. Вместе с тем, белорусы закупил у Венгрии товаров больше, нежели продали, следовательно сальдо стало отрицательным - 14 млн USD 23.2008 г. стал самым продуктивным в это пятилетие и составил 345,9 млн USD с небольшим перевесом в сторону Венгрии - 2,3 млн USD. Несмотря на то, что 2009 г. был достаточно продуктивным в политическом отношении, кривая состояния торгово-экономических отношений пошла вниз. Товарооборот заметно снизился и зафиксировался на отметке 206,6 млн USD. Как показывает статистика до 2018 г. показа-

22 Протокол между Министерством иностранных дел Республики Беларусь и Министерством иностранных дел Венгерской Республики о создании Рабочей группы по экономическому сотрудничеству (03 VI 2004), https://pravo.by/document/?guid=2012\&oldD oc=2004-87/2004-87(048-054).pdf\&oldDocPage=1 (14 VII 2020), Е. Тавгень, Развитие внешнеторгового сотрудничества Республики Беларусь с Венгрией, [в:] Стратегия развития экономики Беларуси: вызовы, инструменты реализации и перспективы, т. 2, Минск 2019, с. 427-431.

23 Данные о внешней торговле Республики Беларусь по отдельным странам в 2019 г., https://www.belstat.gov.by/ofitsialnaya-statistika/realny-sector-ekonomiki/statistika-vneshneekonomicheskoy-deyatelnosti/vneshnyaya-torgovlya-tovarami/godovye-dannye/importtovarov-v-respubliku-belarus-po-otdelnym-stranam-vne-sng/ (15 VII 2020). 
тели импорта уступали экспортным ${ }^{24}$. Сальдо товарооборота сохранялось отрицательным. 2019 г. был завершен с показателем в 253,7 млн USD, из них 131 млн USD составил экспорт ${ }^{25}$. Стороны вышли на положительные показатели торгового сальдо. Следует отметить, что Венгрия традиционно входит в 30 торговых партнеров Беларуси и не более того.

Должностные лица разных уровней неоднократно отмечали, что товарооборот между странами далек от реального внешнеторгового потенциала обоих партнеров. Об этом говорил глава белорусского государства в январе 2019 г. и ему вторил министр иностранных дел и внешней торговли Венгрии П. Сийярто ${ }^{26}$. В 2020 г. скромными назвал объемы экономического сотрудничества премьер-министр Венгрии В. Орбан в ходе официального визита в Минск ${ }^{27}$. Очевидно, что причины нестабильного товарооборота кроются отнюдь не в политических отношениях. На фоне достаточно динамично развивающегося политического диалога, экономические отношениях достигли определенного пика и совершают только небольшие отклонения в ту или другую сторону.

Причины такого состояния товарооборота носят комплексный характер. В первую очередь, необходимо выделить общую проблему торговли Беларуси со странами ЕС - это узкая экспортная корзина. В 2003 г. Посол Республики Беларусь в Венгрии отмечал этот фактор, как сдерживающий динамику двусторонней торговли ${ }^{28}$. Вместе с тем, Посол высказал предположение, что Венгрия могла бы стать для белорусской продукции трамплином в ЕС. Как известно, в 2004 г. Венгрия стала членом ЕС. В июне 2020 г. после визита премьер-министра Венгрии В. Орбана в Беларусь, Посол Республики Беларусь в Венгрии в своем интервью акцентировал внимание на положительных изменениях, которые в конечном итоге и позволи выйти на положительное сальдо в торговле. Прежде всего, в экспортных поставках в Венгрию лидирующие позиции перешли к поставкам железнодорожных вагонов и комплектующих - 48\%. Второе место сохраняют продукты

24 Ibidem.

25 Визит Виктора Орбана - новый этап белорусско-венгерского сотрудничества (4 VI 2020), https://polpred.com/?ns=1\&cnt=32\&cat_a=1 (15 VII 2020).

26 Минск - Будапешт: о развитии сотрудничества по всем направлениям (14 I 2019), https://www.tvr.by/news/prezident/minsk_budapesht_o_razvitii_sotrudnichestva_po_vsem_ napravleniyam_(12 VII 2020).

27 Премьер-министр Венгрии: „Мь мало разговариваем друг с другом, и объем экономического сотрудничества тоже скромен" (5 VI 2020), http://www.ctv.by/premer-ministrvengrii-my-malo-razgovarivaem-drug-s-drugom-i-obem-ekonomicheskogo-sotrudnichestva (16 VII 2020).

28 Беларусь Венгрия: Мы разные, но торговле это не вредит (17 VI 2003), https://neg.by/ novosti/otkrytj/belarus----vengriya-my-raznye-no-torgovle-eto-ne-vredit-2466 (11 VII 2020). 
нефтепереработки - 23\% и третье тракторы и комплектующие - 13,1\%29. Таким образом, можно говорить о том, что Беларуси в торговле с Венгрией удалось решить проблему превалирования в поставках продуктов нефтепереработки.

Серьезным препятствием для проникновения на рынок Венгрии и ЕС в целом является жесткая конкуренция. Сложность заключается не в том, что Беларуси нечего предложить, а в том, чтобы найти свою нишу на венгерском рынке. Трендом в высокоразвитых странах является высокотехнологичная продукция с высокой добавленной стоимостью. А Беларусь в последние годы заметно сократила долю данной продукции в экспорте и этот процесс продолжается ${ }^{30}$.

Это значит, что для Беларуси важно развивать такие производства, однако они требуют привлечения инвестиций. И желательно прямых инвестиций в реальный сектор экономики ${ }^{31}$. В отношениях с Венгрией это еще одна значимая проблема. По состоянию на апрель 2019 г. объем венгерских инвестиций составил 2,13 млн $\mathrm{USD}^{32}$. Если сравнить с другими странами Вышеградской группы, то Венгрия занимает самое последнее место. К примеру, Польша инвестировала в Беларусь 445 млн USD, Чехия - 104,5 млн USD, Словакия - 5,1 млн USD. Вместе с тем, страны подписали межправительственное Соглашение о содействии осуществлению и взаимной защите инвестиций в 2019 г. ${ }^{33}$. На это потребовалось 10 лет.

Несмотря на указанные выше сложности, стороны в целом определили секторальные приоритеты и развивают взаимодействие по разным направлениям. Так, венгерские власти и деловые круги заинтересованы в таких отраслях как железнодорожный транспорт, деревообработка, IT-сфера и атомная энергетика. Собственно интересы сторон совпадают, так как указанные отрасли являются своеобразной визитной карточкой белорусской экономики. В настоящее время самыми успешными стали такие

29 Визит Виктора Орбана - новый этап белорусско-венгерского сотрудничества (4 VI 2020), https://polpred.com/?ns=1\&cnt=32\&cat_a=1 (15 VII 2020).

30 Е.Л. Давыденко, Внешнеторговая политика стран с малой экономикой, Минск 2013, c. 13, https://elib.bsu.by/handle/123456789/106975 (15 III 2020).

31 Н.С. Шалупаева, Опыт стран Вышеградской группы в развитии внешней торговли за счет привлечения прямых инвестиций: выводы и правомерность адаптации, [в:] Стратегия развития экономики Беларуси: вызовы, инструменты реализации и перспективъl, Минск 2018, с. 147-149.

32 Торгово-экономическое сотрудничество с Венгрией, http://hungary.mfa.gov.by/ru/bilateral_relations/trade_economic/bdf007e925410683.html (3 VII 2020).

33 Беларусь рассчитывает на активизацию сотрудничества с деловым сообществом Венгрии - Макей (14 I 2019), https://www.belta.by/politics/view/belarus-rasschityvaet-naaktivizatsiju-sotrudnichestva-s-delovym-soobschestvom-vengrii-makej-332554-2019/?utm_ source=belta\&utm_medium=news\&utm_campaign=accent (12 VII 2020). 
совместные проекты как выпуск двухэтажных поездов „KISS”, которые выпускаются белорусской компанией $3 \mathrm{AO}$ „Штадлер Минск”. Венгрия подписала договор на поставку 40 таких поездов, первый из них был отправлен в Венгрию в 2019 г. $^{34}$. Серьезные позиции Беларусь занимает в поставках тракторов, около 30\% общей доли поставок в этом секторе. Товаропроводящяя сеть предприятия ООО „Беларус Трактор” успешно выполняет свои функции в Венгрии ${ }^{35}$. Активно развивается сотрудничество двух стран в сфере фармацевтики. Сегодня одним из наиболее перспективных направлений называют атомную энергетику. В ходе визита В. Орбана был подписан Меморандум о сотрудничестве в энергетической сфере. В качестве подтверждения серьезности намерений может служить встреча министра энергетики Беларуси с Послом Венгрии и обсуждение возможностей привлечения белорусских строителей к работам на объектах инфраструктуры атомной электростанции „Пакш-2”36.

\section{Выводы. Сильные и слабые стороны, перспективы}

Подводя итог, необходимо отметить, что белорусско-венгерские отношения являют собой пример модели взаимодействия двух средних государств, ограниченных в своих возможностях членством в региональных объединениях. Характеристиками данной модели являются достаточно высокий уровень политических отношений государств, при этом обмен визитами на высшем уровне не является обязательным условием для развития сотрудничества. Это скорее показатель для модели отношений ведущих государств. Важное значение придается членству в международных и региональных организациях, которые повышают устойчивость страны и предоставляют более широкие возможности для развития в разных сферах. Двусторонний формат позволяет декларировать национальные интересы как приоритетные над коллективными. Вместе с тем, данные подходы не находят реального воплощения. Развитие сотрудничества в экономической сфере детерминировано законодательством наднациональных объединений.

34 Венгрия закупит двухэтажные поезда, сделанные в Беларуси (3 III 2020), https://reform. by/vengrija-zakupit-dvuhjetazhnye-poezda-sdelannye-v-belarusi (17 VII 2020).

35 Министр сельского хозяйства Венгрии высоко оценил белорусские тракторы (30 I 2019), http://www.belarus-mtz.by/ministr-selskogo-xozyajstva-vengrii-vysoko-ocenil-belorusskietraktory.html (18 VII 2020).

36 Беларусь и Венгрия нарастят сотрудничество в атомной энергетике (25 VI 2020), https://eurasia.expert/belarus-i-vengriya-narastyat-sotrudnichestvo-v-atomnoy-energetike/ (18 VII 2020). 
Указанные параметры позволяют определить характер белорусско-венгерских отношений как циклический, с периодами подъема и спада. Ассиметричность региональных структур является ключевым фактором ограничения возможностей действий двух стран. Беларусь и Венгрия вынуждены выстраивать политическую повестку в соответствии с основными принципами ЕС и ЕЭС. Анализ политического сотрудничества показывает, что Венгрия никогда не отступала от политики ЕС в отношении Беларуси. Вместе с тем, сегодня Венгрия заявляет о необходимости полной отмены санкций в отношении Беларуси, проявляя тем самым национальное видение внешней политики, что в целом укладывается в вышеуказанную модель. Визит премьер-министра Венгрии в Беларусь в июне 2020 г., впервые за более чем четверть века с момента установления дипломатических отношений, свидетельствует о том, что страны не испытывали серьезных сложностей в развитии отношении без наличия данного компонента. Кроме того, визит В. Орбана в период осложнения отношений с ЕС в связи с выборами в Беларуси является дополнительным подтверждением декларирования приоритета национальных интересов над подходами ЕС.

Относительно стабильный характер политического диалога двух стран напрямую связан с экономическим измерением - планами по диверсификации торговли обоих стран. Причем Венгрия рассматривает Беларусь как промежуточное звено в реализации программы „Открытие на Восток”. Беларусь стремиться не только открыть новые рынки для товаров, но и найти в Венгрии своего рода защитника интересов Беларуси в ЕС. Это особенно важно в связи с имеющими постоянных характер трениями обоих сторон. Выбор Беларусью Венгрии для реализации этих планов можно полагать вполне обоснованным, так как российский фактор не выступает в качестве сдерживающего. Руководство Венгрии неоднократно заявляло о необходимости восстановления диалога с Россией. Вместе с тем, необходимо отметить, что Беларусь традиционно придает огромное значение политическому диалогу, в то время как Венгрия имеет исключительно прагматичные цели сотрудничества. В этой связи разные интерпретации сигналов порождают сложности в реализации экономического сотрудничества.

Для определения перспектив двустороннего сотрудничества необходимо выделить его сильные и слабые стороны.

Сильные стороны:

- отсутствие острых проблемных полей в политической сфере;

- российский фактор не оказывает довлеющего влияния на региональную повестку двусторонних отношений;

- географическое положение Республики Беларусь и развитая инфраструктура выступают в качестве базиса заинтересованности Венгрии в развитии экономического сотрудничества; 
- развитый сектор малых и средних предприятий в Венгрии является существенным фактором в деле продвижении белорусской продукции на венгерский рынок. Особенно сельскохозяйственной техники;

- потенциал расширения торгового сотрудничества в рамках EC не является беспредельным, соотвественно Венгрия будет стремиться к диверсификации экономических связей, что полностью совпадает с политикой Беларуси на современном этапе.

Слабые стороны:

- национальные интересы Венгрии тесно встроены в политику ЕС. Следовательно, ожидать каких-либо исключительных шагов Венгрии в отношении Республики Беларусь в политической сфере (особенно это касается позиции ЕС в отношении выборов) не представляется возможным в ближайшей перспективе. Можно говорить только об определенной доле гибкости;

- Республика Беларусь не является приоритетом внешней политики Венгрии на постсоветском пространстве. Заявления политиков и закрепление на уровне основных государственных документов имеют четкие расхождения;

- экономика Венгрии в значительной степени зависит от иностранных инвестиций и политики ТНК, которые играют ключевую роль в промышленности и сфере услуг. Таким образом, белорусские производители не могут расчитывать на особые государственные преференции, связанные с хорошими политическими отношениями. Данное взаимодействие определяется прагматичными корпоративными интересами. Национальный бизнес в силу ограниченности финансовых средств не в состоянии работать с крупными государственными объединениями Беларуси;

- отсутствие базового соглашения с ЕС в экономической сфере не позволяет субъектам среднего и малого предпринимательства Беларуси получить полноценный доступ к рынкам Венгрии.

Возможности для сторон видятся, прежде всего, в развитии инвестирования в реальный сектор экономики, лидирующие позиции будут сохраняться за Венгрией. Заметные сдвиги в товарообороте могут быть в большей степени связаны с сектором среднего и малого предпринимательства. Что касается государственного сектора, то наиболее перспективным видится сотрудничество на уровне городов и регионов (областей), в силу большей мобильности и оперативного реагирования на запросы рынка. В целом, Беларусь и Венгрия развивают свои отношениях в рамках модели, которая предоставляет им как возможности, так и ограничения. В этой связи важно понимать ее особенности, не ожидать завышенных результатов и не рассматривать политическую сферу, как всемогущий инструмент для запуска широкомасштабного взаимодействия. 


\section{Abstract \\ Olga Lazorkina \\ Belarus - Hungary: \\ pattern of interaction in the conditions of asymmetric associations}

The article focuses on bilateral relations between the Republic of Belarus and Hungary in the context of their membership in the Eurasian Economic Union and the European Union. The author made an attempt to define the model of bilateral cooperation between states limited in their actions by membership in regional associations. The features of the development of political dialogue, which was formed under the influence of the national vision and approaches of the EU as a whole, are analyzed. Special attention is paid to the regional format of relations within the Visegrad Group, CEI and the „Eastern Partnership” initiative. The analysis current state of trade and economic cooperation between Belarus and Hungary is made. The author identifies the strengths and weaknesses of relations, and outlines perspective spheres of cooperation.

The active phase of relations between Belarus and Hungary began in the 2000-s, when the parties finally decided on the vectors of their foreign policy. The launch of the „Eastern Partnership” initiative has played a decisive role in the development of political dialogue and economic cooperation on an ongoing basis. Bilateral relations between Belarus and Hungary are an example for building a model of interaction that is not burdened by a common historical past and based on pragmatism. The fairly active political dialogue between the two countries is based on an economic component. In parallel, the parties actively declare the primacy of national interests over collective ones - the EU and the EAEU. At the same time, the analysis indicates, membership in regional associations significantly limits the possibilities of their implementation in practice. This especially affects the trade and economic sphere of interaction. These factors determine the cyclical nature of relations between Belarus and Hungary. Thus, the bilateral format of cooperation within the framework of asymmetric associations is a sufficiently effective mechanism for the development of a full-fledged dialogue. At the same time, it is important to understand that the political component is secondary to the economic one. This approach allows the parties not to overestimate expectations and to develop mutually beneficial, equal relationships based on pragmatism and real opportunities.

Keywords: Belarus, Hungury, bilateral relations, pattern, political dialog, economic cooperation, regional dimension, Visegrad group, CEI, „Eastern partnership” 


\section{References}

Chesnovskiŭ, M. Je., Strany Sredně̆ Evropy v mezhdunarodnyh otnoshenijah (1989-2014), Minsk 2016.

Davydenko, E. L., Vneshnetorgovaja politika stran s maloj jekonomikoj, https:// elib.bsu.by/handle/123456789/106975 (15 III 2020).

Kontra, F., Druzhit' mogut ne tol'ko sosedi [beseda s Chrezvychajn. i Polnomoch. Poslom Veng. Resp. v Resp. Belarus' F. Kontroj, zapisal V. Gigin], „Belarus. Dumka" 2009, no. 8, p. 44-51.

Shalupaeva, N. S., Opyt stran Vyshegradskor gruppy v razvitii vneshneı̆ torgovli za schet privlechenija prjamyh investiciu: vyvody i pravomernost' adaptacii, [in:] Strategija razvitija jekonomiki Belarusi: vyzovy, instrumenty realizacii i perspektivy: materialy Mezhdunar. konf., Minsk 2018, p. 147-149.

Taras, D. A., Belorussko-vengerskie otnoshenija: 25 let politicheskogo i jekonomicheskogo pragmatizma, [in:] Novye vozmozhnosti pereformatirovanija sistemy mezhdunarodnyh otnoshenij: materialy mezhdunar. kruglogo stola, ed. E. A. Dostanko, Minsk 2017, p. 84-91.

Tavgen, E. O., Razvitie vneshnetorgovogo sotrudnichestva Respubliki Belarus' $s$ Vengriej, [in:] Strategija razvitija jekonomiki Belarusi: vyzovy, instrumenty realizacii i perspektivy, vol. 2, ed. V. I. Belskiy, Minsk 2019, p. 427-431.

Olga Lazorkina - dr historii, docent w Katedrze Służby Dyplomatycznej i Konsularnej na Wydziale Stosunków Międzynarodowych Państwowego Uniwersytetu Białoruskiego. ORCID: 0000-0003-1290-6822 